\title{
Five hundred years on: Some traces of the Reformation in the Church Orders of two South African Reformed Churches - Seen as temporary expressions of the Church Order of the Reformed Synod of Dordrecht in 1619
}

\begin{tabular}{|c|c|}
\hline $\begin{array}{l}\text { Author: } \\
\text { Piet Strauss }{ }^{1}\end{array}$ & \\
\hline $\begin{array}{l}\text { Affiliation: } \\
\text { 'Department } \\
\text { History and Pc } \\
\text { Theology, Uni } \\
\text { Free State, So }\end{array}$ & $\begin{array}{l}\text { f Church } \\
\text { lity, Faculty of } \\
\text { versity of the } \\
\text { uth Africa }\end{array}$ \\
\hline $\begin{array}{l}\text { Correspondin } \\
\text { Piet Strauss, } \\
\text { straussp@ufs. }\end{array}$ & $\begin{array}{l}\text { g author: } \\
\text { ac.za }\end{array}$ \\
\hline $\begin{array}{l}\text { Dates: } \\
\text { Received: } 22 \\
\text { Accepted: } 24 \\
\text { Published: } 12\end{array}$ & $\begin{array}{l}\text { ct. } 2016 \\
\text { lune } 2017 \\
\text { Sept. } 2017\end{array}$ \\
\hline $\begin{array}{l}\text { How to cite th } \\
\text { Strauss, P., } 20 \\
\text { hundred year } \\
\text { traces of the } ~ \\
\text { the Church Or } \\
\text { South African } \\
\text { Churches - Se } \\
\text { temporary ex } \\
\text { Church Order } \\
\text { Reformed Syn } \\
\text { in 1619', HTS } \\
\text { Studies/Theol } \\
73(3) \text {, a4354. } \\
\text { org/10.4102/ }\end{array}$ & $\begin{array}{l}\text { is article: } \\
17, \text { 'Five } \\
\text { on: Some } \\
\text { leformation in } \\
\text { ders of two } \\
\text { Reformed } \\
\text { en as } \\
\text { ressions of the } \\
\text { of the } \\
\text { od of Dordrecht } \\
\text { Teologiese } \\
\text { gical Studies } \\
\text { https://doi. } \\
\text { its.v73i3.4354 }\end{array}$ \\
\hline $\begin{array}{l}\text { Copyright: } \\
\text { (c) 2017. The } \\
\text { Licensee: AOS } \\
\text { is licensed un } \\
\text { Creative Com } \\
\text { Attribution Lic }\end{array}$ & $\begin{array}{l}\text { uthors. } \\
\text { IS. This work } \\
\text { der the } \\
\text { nons } \\
\text { ense. }\end{array}$ \\
\hline Read online: & \\
\hline 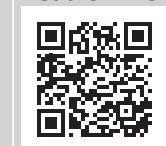 & $\begin{array}{l}\text { Scan this QR } \\
\text { code with your } \\
\text { smart phone or } \\
\text { mobile device } \\
\text { to read online. }\end{array}$ \\
\hline
\end{tabular}

This article examines the influence of the Reformation of the 16th century on the Church Orders of two South African Reformed Churches, namely the Dutch Reformed Church and the Reformed Churches in South Africa. The five so-called solas, namely sola gratia [by grace alone], sola scriptura [by Scripture alone], sola fidei [by faith alone], solus christus [Christ alone] and soli Deo gloria [glory to God alone], are widely accepted as key expressions of the convictions of the Reformation. Although not necessarily in the same terms, the content of the solas are also found in the thought of Calvin. These matters influenced the Synod of Dordrecht (1618-1619) in its acceptance of the Three Formulas of Unity as reformed confessions of faith and its affirmation of the Dordt Church Order. The said South African churches accept the Three Formulas of Unity as confessions of faith and view their church orders as a modern version of the Dordt Church Order - adapted to the demands of the time. This article mainly examines the consequences of sola scriptura and sola fidei on the church orders of the two churches. In terms of these two solas, both have traces of the Reformation after 500 years.

\section{Introduction: Traces of the Reformation?}

There is no consensus as to the identification of the traces of the Reformation of the 16th century. The Lutheran, Reformed, Anglican and Pentecostal Churches can all trace their earliest origin in some way to the Reformation (with many accepting 1517 as the official beginning of the Reformation in Germany, spreading wider from there, cf. De Jong 1987:158-162). There are also differences concerning the grouping of these churches. Protestant Churches is nevertheless a collective noun referring to churches coming out of the Reformation.

In his discussion of the variegated interpretation and variation of Reformational influence, Smit finds the 20th-century theologian Karl Barth's view useful. In doing so he distinguishes four kinds of approaches to the legacy of the Reformation: the antiquarian, ideological, emotional and more Calvin-orientated approach.

In the antiquarian approach, people strive to maintain the status quo and to pursue their former views, convictions and formulations. They create the impression, for example, that Calvin knew everything and that new concepts and developments are unnecessary. They view themselves as Calvinists or Reformational because they adhere to former ideas. In the ideological approach, people select information from the Reformation in order to back their own convictions, preferences, interests and objectives. They thus use the Reformation selectively and apologetically. In the emotional approach, people want to feel Reformational. For them, Reformational devoutness and spirituality are of prime importance. They honour certain figures of the Reformation as heroes because of their devoutness and endeavour to emulate them. In his using of the distinctions of Barth, Smit supports the latter's view that these three approaches all represent a distorted image of the Reformation. And although he doubts Barth's understanding and usage of the Scriptures and confessions in his context, he supports Barth's plea for a fourth approach: Do what Calvin did. This entailed listening to God's Word and reacting thereto with a public confession of faith in word and deed (Smit 2009:188-189).

Smit's criticism, however, does not alter the fact that in his understanding of Barth's sketch of Calvin the latter can be linked to three of the solas of the Reformation: sola scriptura, sola fide and 
soli Deo gloria (by Scripture alone, by faith alone and glory to God alone). The five solas, which include these three as well as sola gratia and solus Christus, are widely accepted as a key expression of the spiritual legacy of the Reformation: a Reformation that was to influence faith and life, church and society, the totality of life for God in a reformational way (NGK 2007 [2011]:13-17).

This article, however, is restricted to a summary of the legacy of John Calvin (1509-1564), the Reformer from Geneva and spiritual father (leader) of reformed churches. Ecumenically these churches form the World Communion of Reformed Churches and the smaller International Conference of (more 'conservative') Reformed Churches (NGK 2007 [2011]:141, 190). In doing so and in order to prevent too broad an approach, we limit this study to the essence of Calvin on two solas, the Church Order of the Reformed Synod of Dordt (1618-1619) which was instrumental in it and two South African Reformed Churches in their reflection of it. The aim is the latter: the two church orders. The main question is: do these two church orders still show an affinity for the Reformation after approximately 500 years: on sola scriptura as well as sola fidei?

\section{Calvin and Dordt}

The authority of the Bible as the Word of God is important and imperative for John Calvin. For him, theology is biblical exegesis. The Bible through which the Triune God reveals himself as the One and Only Creator and Redeemer and which proclaims God's sovereignty over the entire creation and therefore over church and state (the sola scriptura).

Man's sin and disobedience have deprived him of the ability to know the real God. However, God reveals himself to mankind in Christ. Christ as the only Redeemer was promised in the Old Testament and this promise was fulfilled in the New Testament (according to the sola scriptura). God approaches his people or the church with predestined grace, whereby he makes man believe in his Word and to accept the Word as the only way in which he can be saved (sola scriptura, sola gratia and sola fide). Calvin elaborates on Augustine when he states predestination and reprobation: the so-called twofold predestination - a predestination because of grace with Christ (sola gratia) as the only Mediator (solus Christus), and a reprobation because Christ as Mediator is rejected. According to Calvin, faith is a gift of God's grace (cf. Calvin in Sizoo II s.a.:5-8). He thus operates with sola scriptura, sola gratia, sola fide and solus Christus.

De Jong and Praamsma point out correctly that Calvin distinguishes three functions of the 10 Commandments: it is the norm for mankind to know its sin, the principles for public life and the rule for man's gratitude to God - for redemption. The Bible instructs that the state authority must protect the church and maintain the law of God. By implication God's law also demands equitable labour relations, fair interest, honest work and a life directed to God's glory. For Calvin, this reflects soli Deo gloria - all the glory to God (De Jong 1987:195-196; Praamsma s.a.: 255-272; cf. Calvin in Sizoo III s.a.:557).

Against this background the Synodical Commission on Doctrine and Current Affairs of the General Synod of the Dutch Reformed Church or DRC (2007) rightly mentions in its report to the Synod that these five solas are a concise way of expressing the key issues of being reformational - a clear current in the Reformation (NGK 2007 [2011]:13-17). For many Reformed people the solas are the key issues of the actual Reformation.

Smit also describes the solas by implication from man's side or experienced by the believers. He mentions the guiding and liberating power of five key motives in the Reformation: life in the presence of God or coram Dei; trust in the Word of God; involvement in the fullness of life; awareness of one's weaknesses; and life through the power of the Holy Spirit (Smit 2009:224).

Thus far, little mention has been made on the role of the Holy Spirit in the thoughts of Calvin and the Reformation.

\section{Father, son and Holy Spirit and the solas}

Jonker correctly calls Calvin the theologian of the Holy Spirit. According to him, the doctrine of the Holy Spirit forms the nature of Calvin's entire theology. Calvin involved the Spirit in the fulfilment of predestination or salvation. For Calvin, the Word was more than simply the living Word of sermons. For him, the Scriptures as used by the Holy Spirit determine human life and highlight God's will for the life of his people.

Jonker indicates Calvin as an exponent of the 'teologie van die derde artikel' [theology of the third article] or of the Holy Spirit which, in the Apostles' Creed, follows the confession of God the Father and God the Son, their being and work. The articles mention ' $g l o i^{\prime}$ ' [believe in God] the Father, the Son and the Holy Spirit, but 'glo aan' [believe in the institution] the holy Christian church. This is about belief in the Triune God rather than belief in the valuable elements of creation which the three Persons of God each achieve. The third article in the Apostles' Creed addresses the Holy Spirit and what he does: the creation of the church as the community of saints; the forgiveness of sins; the resurrection of the body; and eternal life (Jonker 1994:22, 38-39; cf. Calvin in Sizoo III s.a.:226-314, Sizoo IV s.a.:182-183).

From the Creeds of the Apostles, of Nicea and Athanasius which is dealt with as ecumenical creeds in the Dutch Creed or Confessio Belgica (CB) and the Heidelberg Catechism (HC), Calvin works in a Trinitarian direction, as far as salvation in Christ is concerned.

The five solas can only operate through the Triune God. God the Father decides and rules over man's salvation and obedience; salvation is mediated by Christ as the mediator and Redeemer who as God also becomes man, dies and 
resurrects, and God the Holy Spirit effects redemption and new life in Christ through the Word (cf. Calvin in Sizoo I s.a.:102-144).

Words such as 'erfenis' [legacy], 'kernmotiewe' [key motives] and 'kernsake' [key issues] describe constants that must, in all situations, yield a reformational identity. The traces of the Reformation of 500 years ago are recognised at present from the cherishing of, or using the solas of that time (Strauss 2010:7).

The question now is: are there after nearly 500 years still traces of this Reformation in the church orders of two reformed churches in southern Africa, the Reformed Churches in South Africa (RCSA) and the DRC? True to the title of this article ('some traces'), the search for these traces is restricted to two aspects: the result of sola scriptura and sola fide. However, these two solas as inextricably linked to the other solas. The implementation of both solas is therefore not simple, but still determining in some of the provisions of the church orders.

\section{The Church Order of Dordrecht and of the Reformed Churches in South Africa and the Dutch Reformed Church}

The explicit reformational wish or disposition in the Church Orders of the RCSA and the DRC is echoed by each of them in their own way.

The National Synod of Dordrecht (1618-1619) decided on two issues for churches in the Dutch Reformed tradition: the establishment of the Three Formularies of Unity (CB, $\mathrm{HC}$ and the Canons of Dordt or CD) as their confessions of faith and the finalisation of the Church Order of Dordt (DCO). The acceptance of the Three Formularies originated from the earlier acceptance of the $\mathrm{CB}$ and $\mathrm{HC}$ at the Convent of Wesel (1568) and the National Synod of Emden (1571) as their Two Formularies of Unity (Dutch: 'eenigheid'), implying that this expresses their united belief. In Wesel, for example, ministers were expected to verbally declare their agreement with the Two Formularies. Emden amended this agreement to a signing of the Formularies (Strauss 2006:650-651). Upon this, Dordrecht decided in 1619 that signing the confessions of faith follows an agreement with 'een accuraat formulier' [an accurate formulary]. This formulary indicated an agreement with the doctrine formulated ('begrepen in') in the confessions of faith as Scriptural or bound to the sola scriptura (Kuyper s.a.:186-187). Upon accepting the Three Formularies and the DCO, the Dordt Synod brought to a close the dogmatic and church order development at successive Dutch synods after Emden. Kruger et al. talk about Dordrecht (1618-1619) as the dogmatic and canonical 'afsluiting van die Calvinistiese kerkhervorming in die Nederlande' [termination of the Calvinist church reformation in the Netherlands] (Kruger et al. 1966:30).
What enhanced the impact of this Dordrecht Synod in the 17th century was that, as a National Dutch Synod, it was also an ecumenical synod with the drawing up of the CD. $\mathrm{HH}$ Kuyper calls this the first 'Gereformeerde oecumenische concilie' [Reformed ecumenical council]. Delegates from the Reformed Churches in England, Germany and Switzerland were also involved in drawing up the CD (Kuyper s.a.:vi). The acceptance of both the Three Formularies and the DCO bore the traces of Calvin and the Reformation. Reformed confessions of faith and reformed church orders sought their direction by following the constants of the Reformation.

The Three Formularies reflect the solas in the expression of the soteriology of the Reformation (Jonker 1994:23), whereas the DCO focuses on sola scriptura and the sola fidei within the framework of the solas. Examples of these are legion. The sola scriptura is reflected in the Three Formularies' attempt to base their formulations on Scripture alone (NG Kerk-Uitgewers 1982). In addition, faith, as the means whereby the believer accepts God's salvation out of grace and not a worthy task, plays a key role in all three - a reflection of sola gratia and sola fide. This aspect is briefly explained on the basis of the importance of the correlation election-proclamation-faith (or sola gratia, sola scriptura and sola fide) in each of the Three Formularies (Strauss 2010:82). The DCO's emphasis on the fundamental equality of services (offices) and congregations and its provisions for the official nature of public worship and communion-service are an attempt to allow the Word alone to govern - sola scriptura. Officialdom is not aimed at a stiff, heavy atmosphere, but at official supervision to ensure that the preaching occurs in the sign of 'So sê die Here' [Thus says the Lord] or sola scriptura and that the communion shall occur in a dignified and Scriptural manner. The Biblical sola scriptura is directed by the Holy Spirit on man's sola fide and plays the key role in the church service.

In their history, the church orders of both the RCSA and the DRC reflect the wish to be a contemporary expression of the DCO. In principle, this means a bond with the DCO's defining of reformational constants or principles and not with its practical or concrete provisions (Strauss 2010:7, 8). The latter would only confirm Smit's reference to an antiquarian approach to the Reformation.

Both the RCSA and the DRC Church Orders (RCSA CO and DRC CO) follow the DCO's classification of chapters (NGKKO 2013; Visser 1999).

The RCSA CO follows the contents of specific provisions of the DCO, according to topic, number and content, more faithfully and explicitly than the DRC CO. Upon the acceptance of a church order at the first synod of the RCSA in 1862 in Reddersburg, the RCSA accepted the DCO 'aangepas by die landsomstandighede' [adapted to the circumstances of the country] (Kruger et al. 1966:40). Visser states that, since then, various synods have altered the RCSA CO to suit changing times and local circumstances (Visser 1999:v). For the RCSA the acceptance of the DCO, as adapted to contemporary circumstances, means that it follows in the 
footsteps of the Reformation and Calvin as far as church orders are concerned.

Upon the acceptance of the first DRC CO at the first General Synod in 1962, the DRC also strove towards a DCO 'aangepas by die eise van ons dag' [adapted to the demands of our times] (Jonker 1960:35; Kleynhans s.a.:109; Vorster 1960:13). Where the RCSA CO follows the DCO's topic, number and articles more faithfully, the DRC CO follows the DCO in some expressions and its divisions in chapters. It is, however, a less explicit emulation of the DCO than the RCSA CO.

There are traces of the DCO's constants in both the RCSA CO and the DRC CO. These constants direct the approach of both church orders and result in keeping to sola scriptura and sola fide - the Reformational aspects to which this article briefly pays attention.

For the purposes of this article, the focus on sola scriptura is restricted to the primate of the Word of God and the antihierarchic principle of the offices and meetings in the church. As far as the sola fide is concerned, the focus is on the formulated confessions of faith and the church as a meeting of believers. This point of reference should also be reflected in its typical church activities.

The DCO's concrete point of departure of the sola scriptura leaves, for example, traces in its articles 31 and 84. DCO article 31 stipulates that majority decisions of major assemblies (traditionally the meetings in which more than one church or congregation is involved, Strauss 2010:51) shall be adhered to 'vast en bondig' (firmly and succinctly) by all in the church, unless it is proven that it is against the Word of God (DCO Pont 1981:180). Two issues require our attention. Firstly, it goes without saying that the sovereignty of the Word is accepted in church meetings. In the DCO it is thus only named and not motivated. In addition, decisions are only authoritative if backed by the Word. Decisions must rest on the Word and thus on Christ's authority (Jonker 1965:11). Secondly, the DCO neglects to decide who will make these decisions on Scripture in the church. As formulated by the DCO, this is not specified and open to every member, church council or classis. The procedure or order is not spelled out in the case of differences of decisions. This would later cause problems and schism in the church (De Jong 1987:376).

The DCO's adherence to the sola fide is, for instance, clear in articles 53 and 61. Those who act as ministers or professors in theology with the view to training in ministry must sign the 'belijdenis des geloofs' (confession of faith) of the 'Nederlandsche kerken' [Dutch churches]. A refusal to do so can lead to their dismissal (DKO Pont 1981:182). This implies that a confessionoriented ministry of the Word is also oriented to Scripture or sola scriptura. Faithfulness to the confessions implies maintaining sola scriptura as the essence of Reformation. The Dordt Synod (1618-1619) decides on a formulary at the signing of the confessions of faith. Dordt endorses the Three Formularies because the formulated faith concurs with Scripture (Strauss 2006:660).
The relation election-proclamation-faith, which distinguishes between the believers (the church) and the non-believers, is also evident from the DCO's arrangements for communion. Nobody shall be allowed at the communion table unless she/ he makes a 'belijdenis der Gereformeerde religie' [confession of the Reformed religion] (DCO Pont 1981:183). That only believers can meaningfully go to communion depends, for the DCO, on a later distinction. This distinction provides that both sacraments, namely baptism and communion, refer to God's alliance of grace with his believing children and their children. At their baptism, children are guaranteed their incorporation in the alliance and at communion that they remain as believers in the alliance. Only a believer may take communion because he/she eats his/her own bread and drinks wine within the context in a spiritual and believing manner (Strauss 2010:100-101).

The question now is whether key aspects of the Reformation and in the thoughts of Calvin through the DCO also leave traces in the RCSA CO and DRC CO?

\section{Traces of the Reformation in the Dutch Reformed Church Church Orders}

A problem with traces of the Reformation in the DRC CO is that successive General Synods, which can alter the Church Order, do not address these in a unanimous and consciously reformational or Dordt-orientated way. There is no guarantee for this. In addition, the DRC houses different religious traditions that are not necessarily knowledgeable and active on the church order (Strauss 2015:100-101).

Since the first DRC CO in 1962, and unlike the DCO that does not describe this, article 1 of the DRC CO stipulates that the DRC is 'gegrond' [founded] on the Bible as the holy and infallible Word of God. It is clear from the following sentence that this foundation includes the 'leer begrepen in' [doctrine included] in the Three Formularies (Dordt). The sentence specifies that the doctrine which the church confesses in agreement with God's Word (the Dordtse because or 'quia' point of view) is 'uitgedruk' (expressed) in the reformed Three Formularies of Unity. There is no mention of the three ecumenical confessions, namely the Apostles' Creed, Nicea and Athanasius (NGK-KO 1964:2).

At first glance, this article abounds in reformational traces. The DRC complies with the Bible as the Word of God. In a few words, the Bible is used as the canon of the church and the objective will of God. For the DRC CO, the Bible as the Word of God, is a given. The Bible is the objectively recognised Word of God, not only in a specific situation, and it is not simply the vulnerable human witness of God and his revelation. This article is based on the sola scriptura and accepts the Bible faithfully as the Word of God.

The DRC CO goes even further. What is believed not only to be based on the Bible, but also a standard for the DRC, are 
the Three Formularies of Unity. The Bible is the first and the confessions the second norm of the DRC - a second norm which should be based on the Bible. Typical of the Reformation, sola scriptura and sola fide are implied on the basis of sola gratia. In addition, the DRC is also a practising church - a characteristic of both the church of the Reformation and the Dordt tradition (Jonker 1994:5; Strauss 2008:106-110).

The reason why the three ecumenical confessions are not mentioned is that they are already quoted in article 9 of the CB while the Apostles' Creed is addressed in the HC (NGK 1982:14, 44-56). A lack of knowledge leads to a suggestion at the General Synod of 2013 that the ecumenical confessions be explicitly added (NGK-KO 2013:1). The inclusion of the ecumenical confessions of faith indicates the Reformation's wish not to have a sectarian break with the general Catholic Church, but to identify itself, beyond the dark Middle Ages, with the holy general Christian church (heilige algemene Christelike kerk) of the first five centuries. This realisation is still very much alive among reformational Christians. In the same vein, Jonker mentions a decision concerning the standard of church membership at the General Synod of 1986 of the DRC that keeps the latter within the holy general Christian church. This standard is that church membership is determined by faith in the Triune God - the sola fidei and nothing else (Jonker 1998:191), a standard that also indicates that the DRC as an offspring of the Reformation wanted to stay within the general church.

The General Synod of 1998 decides that the formulated faith in the Three Formularies concurs with God's Word. It is thus not about a quia, stating that everything in the confessions including every punctuation mark, phrase and Scripture concurs with Scripture. The Three Formularies formulate Christian faith as their main objective and, in doing so, they are authoritative and Scriptural (NGK 1998:414-415). Authors interpret this attitude as being Dordt-like (De Gier 1989:285). A similar point of view is mentioned in the Church Order of a sister church, the Christian Reformed Church in North America (Engelhard \& Hofman 2001:50-51).

The deference for the principle of sola scriptura is also apparent in article 48 of the DRC CO as far as public worship is concerned. This article describes public worship as a meeting between God and his congregation, in which the offices take the lead in preaching the Word. A minister of reformed confession, as a proven existence of the Word, can lead a public worship (NGK-KO 2013:12). Although not expressly stated each time, the administration of sacraments also takes place during public worship. Sacraments without the Word and Spirit and the faith of the member - sola fide are not sacraments (NGK-KO 2013:13; Strauss 2010:98). As in the DCO, the official supervision over the sacraments in the DRC CO is directed at its Scriptural use. Often, this supervision requires the faith and individual choice of the person who takes communion because the DRC has practically removed its church councils from its supervision and control in this regard (Strauss 2010:101).

The principle of sola scriptura also forms the basis of antihierarchical traces in the DCR CO. Like article 84 of the DCO (Pont 1981:186), article 4 of the DRC CO (NGK-KO 2013:2) declares the relationship between the specific offices as equal and anti-hierarchical. The same tendency is observed between the meetings of the church. Article 20 of the DRC CO 2013 stipulates that every meeting functions with an unalienable 'lent-from-Christ' authority and that major assemblies (classes, presbyteries or circuits and synods assemblies in which more than one congregation is represented) can only bind their minor assemblies (church councils, etc. in which fewer congregations in the same denomination than in the specific major assembly are represented) in the affairs of their own sphere. This article is exemplified in CO-1957 of the Reformed Church in the Netherlands. This Reformed Church in the Netherlands CO tried to be a contemporary issue of the DCO (Nauta 1971:121; Strauss 2010:53-54).

In this respect, the DRC also houses unfinished discrepancies. Firstly, all ministers of congregations and an equal number of vestrymen (thus an unequal number of elders and deacons) are normally deputised to circuits (presbyteries) and synods in the DRC. This implies an office-determined (not congregation-determined, as should be the case in the context of a reformational church) number of ministers in congregations as against an equal number of elders and deacons. In addition, a congregation with three ministers can overrule or dominate a one-man congregation especially on the circuit. This imbalance between congregations as structural equivalent individuals is transferred, by implication, to the General Synod where half of a synod's deputies are determined by the number of confessed members in their congregations. This savours of a people's democracy instead of a Christocracy where the anti-hierarchic principle is used. Your voting power is determined by your confession of faith. Not even believing children, who are allowed to partake in communion, can have their say (NGK-KO 2013:8-12). This is also not about the number of believers that determine numbers in the church, but adult, confessing voters.

In a DRC that is presently subjected to inner division on matters such as homosexuality, unity in the DRC family and experimenting members and officers, this matter demands reformation. The traces of the Reformation and the solas of the Reformation still flow strongly in the DRC. These traces give strength to the name Dutch Reformed Church. Indeed, a reformed church must always reform most profoundly on the basis of the Word of God. It is a Reformation that reforms on the constants or solas of the Reformation and not on a qwasi-political transformation. Reformation requires continuous development in change and not the leaps of revolutionary change of transformation. The latter is often used for any change without thinking (Strauss 2013:81). 


\section{Traces of the Reformation in the Reformed Churches in South Africa Church Orders}

Since 1862, the RCSA has deliberately followed a Dordt Reformation road. Like the DCO and unlike the DRC CO, article 1 of the RCSA CO does not describe the foundation of the RCSA as being the Word of God and the confessions of faith. Neither does RCSA CO describe these two documents. Like the DCO, it starts with an indication that it has to do with the 'goeie orde in die kerk' [good order in the church] for which the services or offices, the meetings, the supervision of the doctrine, the administration of sacraments, ceremonies and church discipline are necessary. It provides the successive topics. Spoelstra calls it the aim and content of the RCSA CO (Spoelstra 1989:23; Visser 1999:1).

Yet, RCSA CO talks of the Bible as the Word of God and it contains clear provisions for the 'suiwere leer' [pure doctrine], which naturally means sola scriptura (Spoelstra 1989:299). For example, article 55 of the RCSA wants to maintain the pure doctrine. Articles 53 and 54 address the endorsing and signing of the Three Formularies by ministers, professors, elders and deacons (Kruger et al. 1966:336; Visser 1999:217).

With reference to Scripture as norma normans [the first norm] and the confessions of faith as norma normata [the second norm as based on the Bible], Kruger et al. hold that the church's confessions of faith have spiritual and ecclesiastic authority. They come close to the formulated faith ('vervat in' or contained in the Three Formularies) of the DRC: spiritual authority because it expresses beliefs and ecclesiastic authority because the confessions of faith are, according to canon law, the accord or explicit agreement of the church community (Kruger et al. 1966:332). For Spoelstra, the signing of the confessions of faith is also the signing of the correct 'leer' [doctrine]. He uses the words 'in alles met Gods Woord ooreenkom' [agree in everything with God's Word] as an indication of the quia point of view (Spoelstra 1989:299). The RCSA alleges that the confessions of faith have authority in the doctrine of the RCSA, without making a clear distinction between this doctrine and the phraseology or references associated therewith. Unlike proponents of the authoritative formulated faith in these confessions, because (quia) they concur with Scripture, an attitude in the DRC, they do not give an indication of knowledge of 'oneffenheden' [irregularities] in the confessions of faith - an expression by Herman Bavinck (1911:14-15).

At the administration of sacraments, the RCSA gives no indication as to how this should proceed. Once again, the sola scriptura and sola fide are obvious. At both baptism and communion, the relevant church formulary must be used. This needs to be done because the sacraments are visible preaching of the Word and the formulary, with its focus on and loyalty to the Word, places the signs of the covenant of water, bread and wine into a new context - a context which has to be scriptural too. The administration of the sacraments occurs within public worship and thus officially under ecclesiastic supervision. The sola fide is also present in both. At baptism, it is about a covenant baptism of the children of Christians or believing adults who are not yet baptised their incorporation into the covenant. At communion, it is about persons with, among others, a reformed confession remaining in the covenant (Visser 1999:222-247). In general, unlike the DRC, the RCSA is much more aware of confession in its actions.

Like article 84 of the CDO, article 84 of the RCSA contains an anti-hierarchical provision. In this instance, it is explicitly about the structural equivalence of the church offices and congregations or churches (Visser 1999:318). This principle is also interwoven in the composition of its classes and synods, of its major assemblies. Like article 36 of the DCO, article 36 of the RCSA CO stipulates that the 'seggenskap' (voice) of the classis over the church council is similar to that of the synod over the classis. The formulation of the Christ-bestowed authority is, however, missing (Visser 1999:163). The objective is clear: no human hierarchy because Christ must reign through his Word and Spirit (Calvin, Sizoo IV s.a.:182).

These few points show the strong awareness for Reformation in the RCSA. The question is whether these churches à la Smit get around to this with word and deed. Like other reformed churches, the RCSA also has its contentious issues post-2000: women in office, homosexuality and being reformed in modern times. The answer to the challenges for church and faith is not only dogma, neither an inside look and consolidating around a known 'being church', despite new pressing times. It is about reformation of church and society on the basis of the constants or key concepts of the Reformation of 500 years ago.

\section{Conclusion}

The continuing reformation after 500 years cannot be linked to the applications or practical uses of the norms or constants of 500 years ago. The progress of continuing reformation is about an implementation in the own time of the key concepts or constants of the Reformation. Put differently: the progress of the reformation is about the life before God, about the Lord's sovereignty in the entire creation, about the sinner's faithful understanding and experience of his and/or her own sin, of grace, redemption and gratitude, about the just or the faithful who live in faith in this life (Koffeman 2009:175).

Reformation implies that man takes God and his Word seriously; that man through the Word and Spirit of God learned to know Christ as the resurrection and life. The reformational churches in South and southern Africa possess this treasure in clay pots, a treasure that influences all spheres of life in a convalescent and healing, as well as inspiring and securing manner.

Formulating a church order to make obedience to the constants of sola scriptura and sola fidei in the church possible, reveals, at least, some traces of the Reformation of the 16th 
century in a reformed church today. Both the DRC CO and RCSA CO reveal some traces in this regard.

\section{Acknowledgements Competing interests}

The author declares that she has no financial or personal relationships which may have inappropriately influenced her in writing this article.

\section{References}

Bavinck, H., 1911, Modernisme en orthodoxie, Kok, Kampen.

De Gier, K., 1989, De Dordtse Kerkorde, De Hartog, Houten.

De Jong, O.J., 1987, Geschiedenis der kerk, Callenbach, Nijkerk.

Engelhard, D.H. \& Hofman., L.J., 2001, Manual of Christian reformed Church government, CRC, Grand Rapids, MI.

Jonker, W.D., 1960, 'Die bevoegdheid van streeksinodes van die nuwe konsep kerkorde', Ned Geref Teologiese Tydskrif (NGTT) 33-37.

Jonker, W.D., 1965, Om die regering van Christus in sy kerk, Unisa, Pretoria.

Jonker, W.D., 1994, Bevrydende waarheid, Hugenote-Uitgewers, Wellington.

Jonker, W.D., 1998, Selfs die kerk kan verander, Tafelberg, Kaapstad.

Kleynhans, E.P.J., s.a., Die kerkregtelike ontwikkeling van die Nederduitse Gereformeerde Kerke in Suid-Afrika 1795-1962, sn, sl

Koffeman, L.J., 2009, Het goed recht van de kerk, Kok, Kampen.

Kruger, L.S., et al., 1966, Handleiding by die kerkorde van die Gereformeerde Kerk in Suid-Afrika, Pro Rege, Potchefstroom.

Kuyper, H.H., s.a., De post acta of nahandelingen van de Nationale Synode van Dordrecht in 1618 en 1619 gehouden, Höveker and Wormser, Amsterdam.
Nauta, D., 1971, Verklaring van de Kerkorde van de Gereformeerde Kerken in Nederland, Kok, Kampen.

Ned Geref Kerk (NGK), 1982, Handelinge van die Algemene Sinode, sn, sl.

Ned Geref Kerk (NGK), 1998, Handelinge van die Algemene Sinode, sn, sl.

Ned Geref Kerk (NGK), 2007 [2011], Handelinge van die Algemene Sinode, sn, sl.

Ned Geref Kerk (NGK-KO), 1964, Kerkorde van die Ned Geref Kerk, NG Kerk-Uitgewers, Kaapstad.

Ned Geref Kerk (NGK-KO), 2013, Die Kerkorde, sn, sl.

NG Kerk-Uitgewers, 1982, Ons glo..., NG Kerk-Uitgewers, Kaapstad.

Praamsma, L., s.a., Calvijn, Zomer en Keunings, Wageningen.

Pont, A.D., 1981, Die historiese agtergronde van ons kerklike reg I, HAUM, Pretoria.

Sizoo, A., s.a., Johannes Calvyn Institutie I, Meinema, Delft.

Sizoo, A., s.a., Johannes Calvijn Institutie II, Meinema, Delft.

Sizoo, A., s.a., Johannes Calvyn Institutie III, Meinema, Delft.

Sizoo, A., s.a., Johannes Calvijn Institutie IV, Meinema, Delft.

Smit, D.J., 2009, Essays on being Reformed, Sun Media, Stellenbosch.

Spoelstra, B., 1989, Gereformeerde kerkreg en kerkregering, Teologiese Skool, Hammanskraal.

Strauss, P.J., 2006, 'Die Dordtse tradisie en binding aan die belydenis', In die Skriflig 40(4), 649-666.

Strauss, P.J., 2008, 'Die Kerkorde van die Ned Geref Kerk: Uitgangspunte ten opsigte van Skrif, belydenis en kerkorde', Acta Theologica 28(2), 104-117.

Strauss, P.J., 2010, Kerk en orde vandag, Sun Media, Bloemfontein.

Strauss, P.J., 2013, 'Kerkwees in die branding, Die Ned Geref Kerk in algemene sinodale verband 1994-2011', Acta Theologica Supplementum 18.

Strauss, P.J., 2015, Gereformeerdes onder die Suiderkruis 1652-2011, Sun Media, Bloemfontein.

Visser, J., 1999, Die Kerkorde in praktyk, EFJS, Orkney.

Vorster, J.D., 1960, 'Die kerkorde van die Ned Geref Kerke: Besware daarteen en betekenis daarvan', Ned Geref Teologiese Tydskrif (NGTT) 12-18. 